\title{
EFFECTS OF CONTINUOUS VERSUS BOLUS INFUSION OF ENTERAL NUTRITION IN CRITICAL PATIENTS
}

\author{
Letícia Faria Serpa, Miako Kimura, Joel Faintuch and Ivan Ceconello
}

SERPA LF et al. - Effects of continuous versus bolus infusion of enteral nutrition in critical patients. Rev. Hosp. Clin. Fac. Med. S. Paulo 58(1):9-14, 2003.

PURPOSE - Enteral alimentation is the preferred modality of support in critical patients who have acceptable digestive function and are unable to eat orally, but the advantages of continuous versus intermittent administration are surrounded by controversy. With the purpose of identifying the benefits and complications of each technique, a prospective controlled study with matched subjects was conducted.

PATIENTS AND METHODS - Twenty-eight consecutive candidates for enteral feeding were divided into 2 groups (n $=14$ each) that were matched for diagnosis and APACHE II score. A commercial immune-stimulating polymeric diet was administered via nasogastric tube by electronic pump in the proportion of $25 \mathrm{kcal} / \mathrm{kg} / \mathrm{day}$, either as a 1-hour bolus every 3 hours (Group I), or continuously for 24 hours (Group II), over a 3-day period. Anthropometrics, biochemical measurements, recording of administered drugs and other therapies, thorax X-ray, measurement of abdominal circumference, monitoring of gastric residue, and clinical and nutritional assessments were performed at least once daily. The principal measured outcomes of this protocol were frequency of abdominal distention and pulmonary aspiration, and efficacy in supplying the desired amount of nutrients.

RESULTS - Nearly half of the total population (46.4\%) exhibited high gastric residues on at least 1 occasion, but only 1 confirmed episode of pulmonary aspiration occurred (3.6\%). Both groups displayed a moderate number of complications, without differences. Food input during the first day was greater in Group II (approximately 20\% difference), but by the third day, both groups displayed similarly small deficits in total furnished volume of about $10 \%$, when compared with the prescribed diet.

CONCLUSIONS - Both administration modalities permitted practical and effective administration of the diet with frequent registered abnormalities but few clinically significant problems. The two groups were similar in this regard, without statistical differences, probably because of meticulous technique, careful monitoring, strict patient matching, and conservative amounts of diet employed in both situations. Further studies with additional populations, diagnostic groups, and dietetic prescriptions should be performed in order to elucidate the differences between these commonly used feeding modalities.

\section{DESCRIPTORS: Enteral nutrition. Tube feeding. Critical patients. Pulmonary aspiration.}

Enteral alimentation is the preferred modality of support for seriously ill patients who have acceptable gastrointestinal function but are unable to maintain oral diet. Advantages of enteral alimentation include enhancement of intestinal mucosal integrity and nutrient absorption ${ }^{1}$, improvement of metabolic and immune response $^{2,3}$, and reduction of costs ${ }^{4,5}$ and complications ${ }^{6-8}$.

Nevertheless, difficulties inherent in critical populations may still interfere with enteral feeding and create

From the Intensive Care Unit, Hospital Oswaldo Cruz Nursing School and Nutrition Group, Hospital das Clínicas, Faculty of Medicine, University of São Paulo. Received for publication on December 4, 2001. risks for the patient. Prominent among these are derangements of gastrointestinal motility secondary to postoperative ileus, gastric stasis, or enteral hypoperfusion, especially within a context of sepsis, trauma, shock, and organ failures. Specific conditions that may influence peristalsis are mechanical ventilation, sedation, and use of certain antibiotics and other drugs. 
Clinically, these abnormalities usually present themselves in the form of vomiting, diarrhea, abdominal distension, and increased gastric residue between diet infusions. Pulmonary aspiration is the most dramatic consequence, resulting in high morbidity and mortality. Over the years, the role of continuous administration of the diet, in contrast with bolus infusions, has been suggested as a means of preventing complications, but few conclusive advantages have been demonstrated.

With the purpose of analyzing the contribution of each of these alternatives toward the occurrence of gastrointestinal problems and the technical efficiency of tube feeding, a prospective controlled study was undertaken.

\section{PATIENTS AND METHODS}

Population - Two groups of 14 critically ill patients each were randomly assigned to intermittent (Group I) or continuous (Group II) tube feeding. All cases had been admitted to the Intensive Care Unit (ICU) because of clinical or surgical emergencies. Patients were individually matched as closely as possible to controls for diagnosis and APACHE II index ${ }^{9}$ to assure comparable samples.

Criteria of inclusion - Seriously ill adults, males or females, aged 18 to 80 years who were unable to ingest an oral diet, but who had conserved gastrointestinal function, and who had given informed consent.

Criteria of exclusion - Carcinomatosis, irreversible coma, terminal disease; death or discharge before 72 hours of observation; intestinal fistula, obstruction, necrosis, peritonitis, or other contraindication to enteral diet; intolerance to the prescribed nutrients or infusion regimen.

Dietetic routine - All subjects received a complete, polymeric, im- mune-stimulating commercial preparation $(1.0 \mathrm{kcal} / \mathrm{mL}, 56 \mathrm{~g}$ protein $/ \mathrm{mL})$, via nasogastric Dobhoff tube (10 French) and electronic infusion pump. Nurses were instructed to confirm gastric tube position on daily thorax $\mathrm{X}$ ray images taken as a routine in these critical patients, both initially and during daily controls. Whenever the tube was revealed to be displaced, the episode was registered, and the tube was reinserted or repositioned as appropriate. A standard prescription of $25 \mathrm{kcal} /$ $\mathrm{mL}$ was adopted, but actual administered volumes were one of the study variables, as discussed later in this report.

Continuous infusion - The daily desired amount was offered continuously for 24 hours;

Bolus infusion - The total daily feeding period was also 24 hours; however, 8 aliquots were administered over a 1-hour period each at intervals of 3 hours (1-hour infusion period followed by a 2-hour standby period);

General routines - Patients were managed by administration of additional fluids or electrolytes, antibiotics, vasoactive drugs, mechanical ventilation, and other procedures according to medical indications.

Assessment methods - Documentation of the results was done by daily anthropometric and biochemical nutritional assessments, hematologic counts, thorax X-ray, and measurement of abdominal circumference and gastric residual volume. Consumption of vasoactive drugs, sedatives, antibiotics, and mechanical ventilation was monitored, and duration of hospitalization in the ICU and interval between admission and start of enteral alimentation were also documented. Infused volumes along with gastrointestinal and respiratory manifestations were accurately recorded, and night-shift nurses as well as daytime professionals were trained to employ the same methodology. The total observation time was 3 days (72 hours), with observations every 3 hours (24 periods).

Definitions and precautions - Abdominal distension was defined as whenever abdominal circumference increased $3 \mathrm{~cm}$ or more, and high gastric residue was defined as whenever $150 \mathrm{~mL}$ of fluid or more could be recovered immediately before each 3 hour period. Diets were marked with anilin-blue dye so pulmonary aspiration could more easily be recognized, and pneumonia was affirmed whenever a new lung infiltrate at thorax X-ray was accompanied by clinical symptoms, particularly in basilar segments and on the right lung, where aspiration is most common ${ }^{10}$. Isolation of etiologic agents was not performed, since this is routinely done only in cases of transplantation procedures, cancer chemotherapy, immune-suppressive therapy, or AIDS, which did not occur in this study.

The complication rate was calculated per patient and per period of 3 and 24 hours; a single episode of vomiting, diarrhea, or distention was enough to define the case as complicated.

Ethical procedures - Informed consent was obtained from all subjects. The protocol was approved by the Ethical Committee of the Hospital.

Statistical analysis - Results were compared by Mann-Whitney, chisquare, and Student's $t$ tests, as appropriate. A significance level of $5 \%$ was adopted.

Study population - Fifty patients were initially considered for the study, but due to exclusion criteria and matching requirements, only 28 were enrolled.

The groups were comparable regarding age, gender, duration of stay in the ICU, interval until introduction of tube feeding, and several other variables (Table 1). The principal diagnostic categories were neurologic diseases, respiratory insufficiency, heart 
abnormalities, and others. APACHE II scores were $14.7-/+3.7$ for Group I and $15.6-/+3.2$ for Group II. No statistical difference between groups could be demonstrated for these findings as well as for general biochemical and nutritional measurements. One discrepancy was noticed concerning consumption of vasoactive drugs, which was more prevalent in Group I $(P=0.06)$ (Table 2).

\section{RESULTS}

Infusion care - High gastric residue was comparatively common (46.4\% of the total population), along with abdominal distension (28.6\%), and gastric tube displacement $(25.0 \%)$. Vomiting and diarrhea were infrequent (14.3\% each), and 1 case each of pulmonary aspiration and tube obstruction were detected $(3.6 \%)$. These complications are shown on Figure 1 and Table 3.

During continuous infusion, the most frequent aberration was high residual volume and abdominal distension. One confirmed and 1 suspected case of pulmonary aspiration were recorded. The bolus infusion group had similarly high gastric residue volumes and rates of abdominal distension, as well as similar rates of diarrhea and tube displacement.

In almost all circumstances $(26 / 28$ or $92.9 \%$ ), total daily input was smaller than prescribed. A difference of approximately $20 \%$ in the volume deficits could be noticed between the groups $(P=0.01)$ on the first day, with advantage for Group II (Figure 2 and Table 4). However, over the entire observation period, both groups had similar deficits of approximately $10 \%$, without significant differences.

The principal reasons for infusion delay or temporary discontinuation were high residual volume, as well as diagnostic or therapeutic procedures,
Table 1 - Comparison of patients receiving continuous versus intermittent therapy with regard to gender, age, length of stay in the Intensive Care Unit, mortality, and interval until the beginning of enteral feeding.

\begin{tabular}{lccc}
\hline Variable & Intermittent & Continuous & Significance \\
\hline Age & $64.9 \pm 13.9$ & $69.6 \pm 13.2$ & $P>0.05$ \\
Gender (M/F) & $7 / 7$ & $9 / 5 P>0.05$ & \\
Time in Intensive Care Unit (days) & $14.1 \pm 9.3$ & $14.2 \pm 10.2$ & $P>0.05$ \\
Delay until enteral nutrition (days) & $4.5 \pm 5.6$ & $2.2 \pm 1.4$ & $P>0.05$ \\
Mortality & $3 / 14(21.4 \%)$ & $3 / 14(21.4 \%)$ & $P>0.05$ \\
\hline
\end{tabular}

Table 2 - General preoperative findings.

\begin{tabular}{lccc}
\hline Variable & Intermittent & Continuous & Significance \\
\hline Diagnosis & & & \\
$\quad$ Neurologic problems & $6 / 14$ & $8 / 14$ & $P>0.05$ \\
Respiratory insufficiency & $3 / 14$ & $3 / 14$ & $P>0.05$ \\
Heart diseases & $2 / 14$ & $1 / 14$ & $P>0.05$ \\
Miscellaneous troubles & $3 / 14$ & $2 / 14$ & $P>0.05$ \\
Special treatment & & & \\
Mechanical ventilation & $7 / 14$ & $8 / 14$ & $P>0.05$ \\
Sedation & $5 / 14$ & $6 / 14$ & $P>0.05$ \\
Vasoactive drugs & $9 / 14$ & $4 / 14$ & $P=0.06$ \\
Antibiotics & $11 / 14$ & $11 / 14$ & $P>0.05$ \\
Dialysis & $0 / 14$ & $0 / 14$ & $P>0.05$ \\
Nutritional & $23.6 \pm 4.6$ & $23.8 \pm 5.2$ & $P>0.05$ \\
Body mass index $\left(\mathrm{kg} / \mathrm{m}^{2}\right)$ & $3.4 \pm 0.3$ & $3.6 \pm 0.4$ & $P>0.05$ \\
Serum albumin $(\mathrm{g} / 100 \mathrm{~mL})$ & $11.7 \pm 1.7$ & $11.2 \pm 2.2$ & $P>0.05$ \\
Hemoglobin $(\mathrm{g} / 100 \mathrm{~mL})$ & $1397 \pm 1258$ & $1334 \pm 732$ & $P>0.05$ \\
Lymphocyte count $\left.(/ \mathrm{mm})^{3}\right)$ & $1460 \pm 176$ & $1557 \pm 300$ & $P>0.05$ \\
Energy requirements $(\mathrm{kcal})$ & & & \\
Biochemical & $50.3 \pm 35.2$ & $50.3 \pm 30.7$ & $P>0.05$ \\
$\quad$ Blood urea $(\mathrm{mg} / 100 \mathrm{~mL})$ & $1.0 \pm 0.5$ & $1.2 \pm 0.7$ & $P>0.05$ \\
Serum creatinine $(\mathrm{mg} / 100 \mathrm{~mL})$ & $14709 \pm 4946$ & $12287 \pm 4568$ & $P>0.05$ \\
$\quad$ White blood cells $\left.(/ \mathrm{mm})^{3}\right)$ & & & \\
\hline
\end{tabular}

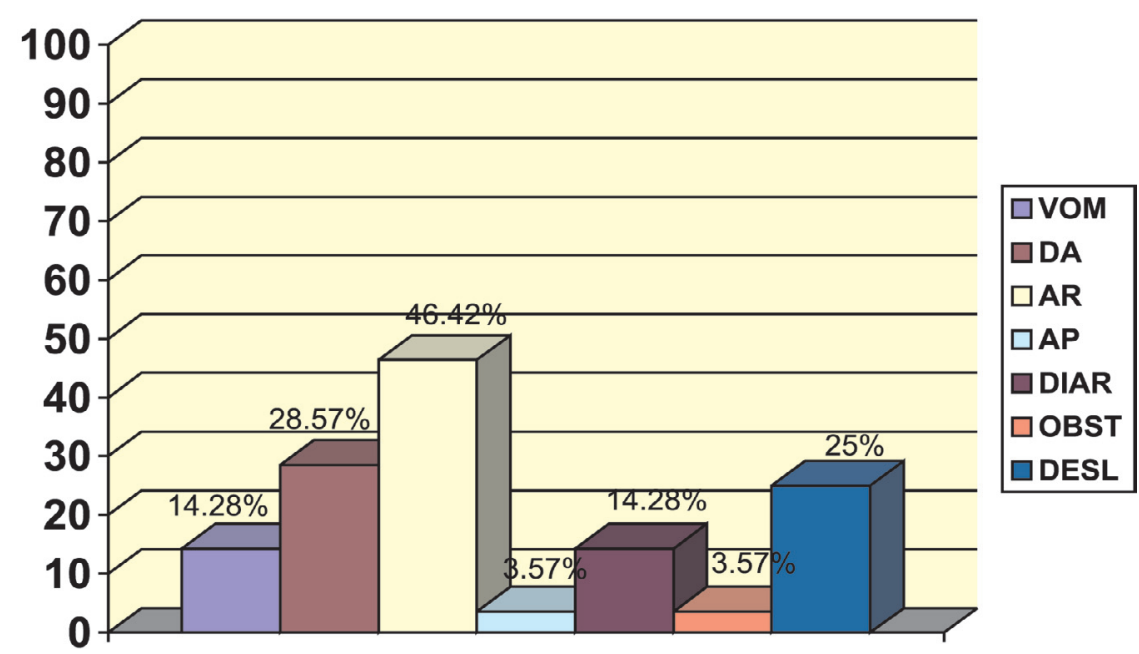

VOM: Vomiting; DA: Abdominal distension; AR: High gastric residual volume; AR: Lung aspiration; DIAR: Diarrhea; OBST: Feeding tube obstruction; DESL : Feeding tube displacement.

Figure 1 - Total abnormalities during enteral alimentation. 
Table 3 - Complications of feeding regimen.

\begin{tabular}{lcccc}
\hline Finding & & Intermittent & Continuous & Significance \\
\hline High gastric residue - & Day 1 & $6 / 14$ & $5 / 14$ & $P>0.05$ \\
& Day 2 & $5 / 14$ & $5 / 14$ & $P>0.05$ \\
Pulmonary aspiration - & Day 3 & $4 / 14$ & $4 / 14$ & $P>0.05$ \\
(* Suspected) & Day 1 & $0 / 14$ & $0 / 14$ & $P>0.05$ \\
(** Confirmed) & Day 2 & $1 / 14 *$ & $0 / 14$ & $P>0.05$ \\
Abdominal distension - & Day 3 & $0 / 14$ & $1 / 14 * *$ & $P>0.05$ \\
& Day 1 & $1 / 14$ & $3 / 14$ & $P>0.05$ \\
Nausea - & Day 2 & $2 / 14$ & $1 / 14$ & $P>0.05$ \\
& Day 3 & $2 / 14$ & $0 / 14$ & $P>0.05$ \\
Vomiting - & Day 1 & $0 / 14$ & $0 / 14$ & $P>0.05$ \\
& Day 2 & $0 / 14$ & $0 / 14$ & $P>0.05$ \\
Diarrhea - & Day 3 & $0 / 14$ & $0 / 14$ & $P>0.05$ \\
& Day 1 & $0 / 14$ & $0 / 14$ & $P>0.05$ \\
Tube obstruction - & Day 2 & $2 / 14$ & $2 / 14$ & $P>0.05$ \\
& Day 3 & $0 / 14$ & $1 / 14$ & $P>0.05$ \\
Tube displacement - & Day 1 & $0 / 14$ & $1 / 14$ & $P>0.05$ \\
& Day 2 & $1 / 14$ & $0 / 14$ & $P>0.05$ \\
& Day 3 & $3 / 14$ & $0 / 14$ & $P>0.05$ \\
& Day 1 & $0 / 14$ & $0 / 14$ & $P>0.05$ \\
& Day 2 & $0 / 14$ & $0 / 14$ & $P>0.05$ \\
& Day 3 & $0 / 14$ & $1 / 14$ & $P>0.05$ \\
& Day 1 & $2 / 14$ & $1 / 14$ & $P>0.05$ \\
& Day 2 & $2 / 14$ & $2 / 14$ & $P>0.05$ \\
& Day 3 & $0 / 14$ & $0 / 14$ & $P>0.05$ \\
\hline
\end{tabular}

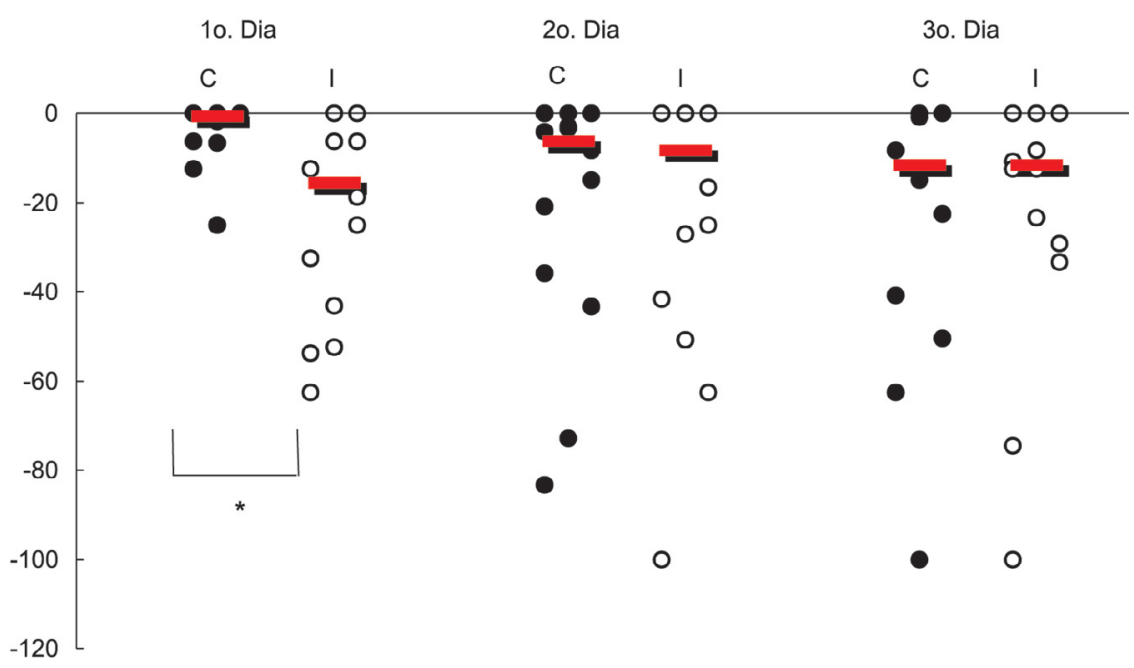

Group I: Open circles; Group II: Black circles; Thick line: Mean daily intake:Statistical difference demonstrated for first day only.

Figure 2 - Registered deficits in dietary intake during 3 days (Prescribed minus infused volume).

Table 4 - Discrepancies between prescribed and administered diet.

\begin{tabular}{lccc}
\hline Diet volume (mL/24 h) & Intermittent & Continuous & Significance \\
\hline Prescribed - Day 1 & 800 & 800 & \\
Administered - Day 1 & $614 \pm 169$ & $766 \pm 55$ & $P<0.05$ \\
Prescribed - Day 2 & 1200 & 1200 & $P>0.05$ \\
Administered - Day 2 & $923 \pm 357$ & $951 \pm 324$ & \\
Prescribed - Day 3 & 1200 & 1200 & $P>0.05$ \\
Administered - Day 3 & $939 \pm 357$ & $900 \pm 350$ & \\
\hline
\end{tabular}

and these problems equally affected both study groups.

\section{DISCUSSION}

Physiologic disturbances of the digestive tract secondary to clinical or surgical conditions are common, and for many years, it has been recommended that enteral nutrition should be introduced slowly and adjusted according to tolerance ${ }^{11-13}$. High-risk cases, such as those here investigated, are substantially more prone to motility derangements ${ }^{14,15}$.

Certain authors advocate continuous administration of the diet as a means of overcoming possible gastric stasis and reflux, yet there is not wide consensus about the efficacy of such an approach ${ }^{5,6,10,14}$.

In the present protocol, great care was devoted to the selection of comparable populations for continuous and bolus infusion to minimize any bias related to associated diseases and organ failures. Diet, gastric tube, dietetic routine, and controls were all well standardized.

An observation period longer than 72 hours would perhaps amplify the differences between the techniques; however, this was not feasible under the conditions of a busy ICU having short overall durations of hospitalization. Also, more aggressive bolus feedings with syringe injections that are typically performed at high pressures and short times would potentially underscore the limitations of one versus the other method. However, it was not the purpose of this project to expose patients to elevated risks or costs, but rather to evaluate the safest and most acceptable hospital routines. It is also worth emphasizing that a serious attempt to recruit 50 patients was done, but because of protocol restrictions, only 28 could be evaluated.

Only 1 variable, consumption of 
vasoactive drugs, was not equivalent between the groups; vasoactive drugs were administered more frequently to patients assigned to Group I (bolus-fed protocol). The main vasoactive agent prescribed was dopamine, and according to Tarling ${ }^{16}$, dopamine sometimes adversely interferes with gastric emptying. Despite this methodological flaw, the virtual lack of differences between the compared techniques indicates that the findings reported in this study are reliable.

Intermittent alimentation did fail to provide as much volume as the continuous modality on the first day, but by the third day, the advantage had disappeared. When true complications are considered, the differences between the two routines were even more subtle and could not be statistically confirmed. It should not be overlooked that both therapies were actually very successful, since total diet-related morbidity was quite low for such a critical population, and nearly $80 \%$ of the nutritional intake goal was reached by 72 hours. It is accepted that whenever $80 \%$ of the energy needs of the patient are supplied by 72 hours, the replenishment program should be considered adequate ${ }^{17}$.

Therefore, it is safe to affirm that the precautions adopted here, such as the use of electronic pumps, slow administration even in cases of bolus prescription, careful selection of diet and positioning of the tube, prevention of abdominal distension or high gastric residues, and constant monitoring of the patients, permitted good results with both of the tested procedures. Further studies are certainly necessary to expand these observations towards longer alimentation periods, populations with other APACHE scores, and different diagnostic categories, so all doubts concerning the choice of ideal feeding procedure in these contexts can be eliminated.

\section{CONCLUSIONS}

Under the conditions of this study it can be concluded that:

1) Total complication rate was comparatively low with either bolus or continuous administration;
2) Continuous administration provided a higher dietary intake on the first day in Group II, but by the third day, no difference remained between the two groups;

3) Both populations displayed a deficit of actually supplied volume when compared with diet prescription, but this shortcoming was small, similar in both groups, and justified in circumstances of critical disease and intensive care;

4) Further studies should include longer alimentation periods and populations with different risk scores to advance the knowledge about these widely adopted therapeutic techniques.

\section{ACKNOWLEDGMENTS}

We are grateful to the staff of the ICU of Hospital Alemão Oswaldo Cruz for valuable assistance and cooperation during this study.

See Editorial related to this article on page 1.

\section{RESUMO}

SERPA LF e col. - Efeitos da administração contínua versus intermitente da nutrição enteral em pacientes críticos. Rev. Hosp. Clin. Fac. Med. S. Paulo 58(1):9-14, 2002.

ANTECEDENTES - A alimentação enteral é a modalidade preferida de suporte em pacientes graves com função digestiva aceitável porém incapazes de se alimentar por via oral, entretanto as vantagens da oferta contínua em contraste com a intermitente são rodeadas de controvérsias. Tendo como objetivo identificar os benefícios e as complicações destas técnicas, realizou-se um estudo prospectivo e controlado com casos pareados.

PACIENTES E MÉTODOS: Vinte e oito pacientes consecutivos candidatos a alimentação enteral foram divididos em dois Grupos ( $n=14)$, pareados segundo diagnóstico e índice APACHE II.Uma dieta polimérica comercial imuno-estimulante foi administrada por sonda nasogástrica e bomba de infusão na proporção de $25 \mathrm{kcal} / \mathrm{kg} / \mathrm{dia}$, em forma de bolo por uma hora a cada três ho- ras (Grupo I), ou continuamente nas 24 horas (Grupo II), durante três dias. Os métodos incluiram antropometria, dosagens bioquímicas, registro de uso de drogas e outras terapêuticas, RX de tórax, circunferência abdominal, resíduo gástrico, e avaliação clínica e nutricional, efetuada no mínimo uma vez por dia. Os principais desfechos colimados neste estudo foram frequência de distensão abdominal e aspiração pulmonar, e capacidade de atingir a meta calórica pretendida.

RESULTADOS: Quase metade da 
população total $(46,4 \%)$ apresentou resíduos gástricos elevados em pelo menos uma ocasião, porém somente foi registrado um episódio confirmado de aspiração pulmonar (3,6\%). Ambos os grupos padeceram de um número moderado de complicações, sem diferenças. O ganho de dieta no Grupo II foi maior no primeiro dia, porém no terceiro dia ambos os grupos exibiam déficits pequenos e semelhantes no ganho dietético, quando comparados com o volume prescrito.

CONCLUSÕES: Ambas as modalidades de oferta permitiram a administração prática e eficiente da dieta, com freqüentes anormalidades registradas porém escassas complicações clinicamente significativas. Os dois grupos se comportaram analogamente, com poucas diferenças nos resultados, provavelmente devido à técnica meticulosa, monitorização cuidadosa, rígido pareamento dos pacientes, e volumes mo- destos da dieta empregados nas duas circunstâncias. Investigações subseqüentes deveriam ser elaboradas com populações, grupos diagnósticos e prescrições dietéticas adicionais, a fim de elucidar as diferenças entre estas modalidades de alimentação comumente usadas.

DESCRITORES: Nutrição enteral. Alimentação por sonda. Pacientes críticos. Aspiração pulmonar.

\section{REFERENCES}

1. GUENTER P, JONES S, ERICSON M - Enteral nutrition therapy. Nurs Clin North Am 1997; 23:651-68.

2. CERRA FB, LEHMANN S, KONSTANTINIDES NN et al. Improvement of immune function in ICU patients by enteral nutrition supplemented with arginine, RNA and menhaden oil is independent of nitrogen balance. Nutrition 1991; 7:193-9.

3. BORLASE BC, BELL SJ, LEWIS SJ et al. - Tolerance to enteral tube feeding diets in hypoalbuminemic critically ill geriatric patients. Surg Gynecol Obstet 1992;174:181-188.

4. SHIKORA AS, OGAWA AM - Enteral nutrition and the critically ill. Postgrad Med J 1997; 72: 395-402.

5. ROCCO O - Gastrointestinal motility and tube feeding. Crit Care Med 1998; 26:104-109.

6. TWYMAN D - Nutritional management of the critically ill neurologic patient. Crit Care Clin 1997; 13:39-49.

7. GIANOTTI L - Effect of route of delivery and formulation of postoperative nutritional support in patients undergoing major operations for malignant neoplasms. Arch Surg 1997;132:1222-9.

8. DALY JM, WEINTRAUB FN, SHOU I et al. - Enteral nutrition during multimodality therapy in upper gastrointestinal cancer patients. Ann Surg 1995; 221: 327-38.
9. KNAUS WA, LEGALL JR, WAGNER DP et al. - Apache II: Severity of disease classification system. Crit Care Med 1985; 13:81829.

10. WINTERBAUER R H, DURNING R B, BARRON E et al.Aspirated nasogastric feeding solution detected by glucose strips. Ann Intern Med 1985; 95:57-68.

11. MAIN BJ, MORRISON DL - Development of a clinical pathway for enteral nutrition. Nutr Clin Pract 1998;13: 20-4.

12. FUhrman M P - Diarrhea and feeding. Nutr Clin Pract 1999;14:83-4.

13. SPAIN DA, MCCLAVE SA, SEXTON LK et al. - Infusion protocol improves delivery of enteral tube feeding in the critical care unit. JPEN J Parent Enteral Nutr 1999;23:288-92.

14. ROMBEAU JL, TAKALA J - Summary of round table conference: gut dysfunction in critical illness. Clin Nutr 1997;16:57-60.

15. RINGEL AF, JAMENSON GL, FOSTER ES - Diarrhea in the intensive care patient. Crit Care Clin 1995; 11:465-477.

16. TARLING MM, TONER CC, WITHINGTON PS et al. - A model of gastric emptying using paracetamol absorption in intensive care patients. Intensive Care Med 1997;.23:256-60.

17. BERRY JK, BRAUNSCHWEIG C A - Nutritional assessment of the critically ill patient. Crit Care Nurs Q 1998; 21:33-46. 